\title{
STATUS OF GREY LEAF SPOT DISEASE IN KENYAN MAIZE PRODUCTION ECOSYSTEMS
}

\author{
Z.M. KINYUA, J.J. SMITH' ${ }^{1}$, G.N. KIBATA, S.A. SIMONS² and B.C. LANGAT \\ National Agricultural Research Laboratories, KARI-NARL, P. O. Box 14733-00800, Nairobi, Kenya \\ ${ }^{1}$ The Food and Environmental Research Agency, Sand Hutton, York YO41 1 LZ, United Kingdom \\ ${ }^{2}$ CABI-Bioscience - Africa Regional Centre, P. O. Box 633, Village Market, Nairobi, Kenya \\ Correspondence author: kinyuazm@gmail.com
}

\begin{abstract}
Grey leaf spot disease (GLS), Cercospora zeae-maydis, which has previously been attributed to diverse pathogen species in other countries, has become a serious biotic constraint to production of maize (Zea mays L.) in Kenya. It is necessary to determine the distribution and aetiology of the disease across all the maize production agro-ecologies in order to inform the development of appropriate management strategies against the disease. Samples were collected from maize growing areas in Kenya with GLS symptoms on maize crops and other plants. On the basis of cultural and morphological examinations, and restricted fragment length polymorphism and taxon-specific PCR analyses, Cercospora zeae-maydis group II and C. sorghi var. maydis were identified from typical GLS lesions on maize, with the former being predominant ( $>96 \%$ of the cases) and distributed throughout the country. The latter exhibited minor incidence $(<4 \%)$ in western Kenya. Nucleotide sequence analyses further provided evidence that C. zeae-maydis group II and $C$. sorghi var. maydis were distinct fungi.
\end{abstract}

Key Words: Cercospora zeae-maydis, Kenya, Zea mays

\section{RÉSUMÉ}

La maladie de tâche grise de la feuille (GLS), Cercospora zeae-maydis, attribuée aux espèces de pathogens diverses dans d'autres pays, est devenue une sérieuse contrainte biotique à la production de maïs (Zea mays L.) au Kenya. Il est nécessaire de déterminer la distribution et l'étiologie de la maladie à travers toutes les régions agroécologques productrices de maïs pour mieux développer des stratégies appropriées de gestion contre la maladie. Des échantillons étaient recueillis dans des régions producteurs du mą̇s au Kenya tenant compte de la présence des symptômes GLS sur les maïs et autres cultures. Sur base des examens culturales et morphologiques ainsi que du polymorphisme de la longueur du fragment isolé et les analyses PCR du taxon spécifique, Cercospora zeaemaydis le groupe II de Cercospora zeae-maydis et $C$. sorghi var. maydis étaient identifiés par des lésions typiques de GLS sur le maïs, ce dernier étant le plus prédominant (> $96 \%$ de tous les cas) et distribué à travers tout le pays avec une incidence mineur de $4 \%$ dans l'ouest du Kenya. L'analyse de séquences de nucléotides avait par la suite montré avec evidence que le $C$. zeae-maydis group II et $C$. sorghi var. maydis étaient de champignons distincts.

Mots Clés: Cercospora zeae-maydis, Kenya, Zea mays

\section{INTRODUCTION}

The first incidence of grey leaf spot (GLS) disease in Kenya was reported in 1995 (National Agricultural Research Laboratories (NARL) disease records, unpublished), although it had been reported in other countries (Latterell and Rossi, 1983; Ward et al., 1993; Ward et al., 1997). GLS is expressed in the form of necrotic lesions, which may coalesce and cause extensive blighting of leaves, thereby reducing the photosynthetic area of maize plants. 
Consequently, there is poor grain filling, which leads to low maize yields. Yield losses caused by GLS were estimated to be in the range of 30-50\% in Kenya (Muriithi and Gathama, 1998) and 30$60 \%$ in South Africa (Ward et al., 1997). Total yield loss may also occur in the absence of control measures if favourable environmental conditions prevail following successful early infection in maize crop fields (Saghai-Maroof et al., 1993). This relatively new disease is, therefore, a serious threat to the food security in Kenya, where the crop is the leading staple food for about $90 \%$ of the population (Anon., 1989; Export Processing Zones Authority, 2005).

Previous reports on GLS, including those from Kenya (Muriithi and Gathama, 1998), have generally considered the disease to be caused by a homogeneous species, namely Cercospora zeae-maydis Tehon and E.Y Daniels. However, recent investigations have shown that $C$. zeaemaydis is composed of two genetically distinct but morphologically similar sibling species, referred to as C. zeae-maydis group I and group II (Wang et al., 1998; Dunkle and Levy, 2000). The latter has subsequently been named C. zeina Crous and U. Braun, sp. nov., while retaining the name C. zeae-maydis for the former sibling species (Crous et al., 2006). Additionally, an assumed variant of $C$. sorghi has been associated with GLS lesions, and has been referred to as $C$. sorghi var. maydis Ellis and Everhart (Shurtleff, 1992; White, 1999). The etiology of the grey leaf spot disease in Kenya was unclear since no comprehensive diagnosis had been carried out.

The objective of this study was to establish the identity, distribution and variability of GLS pathogen(s) in Kenya in order to inform the formulation of sustainable GLS management strategies against the disease in the country.

\section{MATERIALS AND METHODS}

Sample collection. Two extensive surveys were undertaken in the major maize-producing areas of Kenya during the short rains season (September to December) of 2000 and the long rains season (April to August) of 2002. These were the stages when maize crops were between tasseling and physiological maturity, a period within which GLS development is considered to be at its peak (Latterell and Rossi, 1983). Maize leaf samples with symptoms recognised as those of GLS (principally, pale brown or grey to tan, long narrow streaks that become dark, greyish-brown rectangular lesions as the disease develops) were collected along the survey routes at intervals of 10 to $20 \mathrm{~km}$ in order to get representative survey sites within a geographic region or an agro-ecological zone.

Intensive sampling was also undertaken for GLS pathogens on plants other than maize. The plants considered included sorghum (Sorghum bicolor (L.) Moench), wild sorghum (S. verticilliflorum (Steud.) Stapf), Columbus grass (S. almum Parodi), Sudan grass (S. bicolor ssp. bicolor), and Guatemala grass (Tripsacum laxum). Others included pearl millet/bulrush millet (Pennisetum glaucum (L.) R. Br.), napier grass (Pennistum purpureum Scumach.), sugarcane (Saccharum officinarum L.), and wild oat (Avena sp.). The samples were carried in separate envelopes/brown paper bags for subsequent laboratory isolation of fungi. Additional monitoring-based samplings were done in selected high potential areas in July 2008 (during the long rains) for comparison with previous samplings, this time focusing on the maize crop alone.

Isolation and culture of pathogens. Single, well-separated lesions on the sampled materials were examined for sporulation under a binocular microscope. Conidia from separate synnemata were picked with an isolation needle and plated on tap water agar, allowing at least three pickings per leaf sample. The plates were then incubated at $25{ }^{\circ} \mathrm{C}$ for 5-7 days. Hyphal tips from the advancing colony margins were then transferred onto vegetable (V8) juice medium as part of the culture purification process. Purified isolates were kept at $5{ }^{\circ} \mathrm{C}$ and occasionally sub-cultured onto fresh V8 juice medium to maintain fungal viability.

Cultural and morphological identification of isolates. All the isolates obtained from maize and other hosts in various maize production ecosystems were subjected to examinations of morphological and cultural characteristics to determine those isolates with 
Cercospora-like features. The isolates were then assigned tentative species identities by examining their cultural and morphological features such as growth habits, texture and colour of the fungal colonies, and formation, colour, shape and septation of conidia and conidiophores. Additionally, comparison was made with some previously identified Cercospora isolates held in CABI's Genetic Resource Collection (GRC) or donated by other sources. Reference fungi included isolates IMI 385118 (C. zeae-maydis from maize, originating in Kenya), IMI 385119 (C. sorghi var. maydis from maize, Kenya), IMI 168891 (C. sorghi from sorghum, Papua New Guinea), SCOH1-5 (representing C. zeae-maydis group I, from USA), and OYPA16 (C. zeae-maydis group II from USA). Others included IMI 249002 (C. beticola from Beta sp. originating in Germany) and IMI 194862 (C. longipes from sugarcane, Kenya). The reference C. zeaemaydis group I and group II isolates were provided by L.D. Dunkle, Purdue University, USA. Additionally, some C. zeae-maydis isolates from Zimbabwe and South Africa were included in the analyses.

Molecular analyses of isolates. All the isolates, with the exception of those obtained in the 2008 sampling, were grown in potato dextrose broth, PDB (Difco Laboratories, Detroit, USA) to encourage abundant mycelium production for DNA extraction. The cultures were incubated for $10-14$ days at $25{ }^{\circ} \mathrm{C}$ with constant rotary shaking at 200 rpms. The resulting mycelial mass was harvested by filtering through two layers of Mira Cloth (Calbiochem, San Diego, USA) and then frozen at $-20^{\circ} \mathrm{C}$ for about 3 hours before freeze-drying overnight. The freeze-dried mycelium was ground in liquid nitrogen and DNA extracted using the procedure developed by Raeder and Broda (1985).

The following rDNA analysis procedures were employed to target the first and second internal transcribed spacer regions (ITS 1 and ITS 2), portions of the small (18S) and large (28S) nuclear ribosomal DNA genes, and the $5.8 \mathrm{~S}$ rDNA gene of the isolates to authenticitize the cultural and morphological identification and to determine their phylogenetic relationships: restriction fragment length polymorphism (RFLP), PCR amplifications with Cercospora-specific primers, and nucleotide sequence analysis.

Restriction fragment length polymorphism (RFLP) analysis. Universal primers ITS1 (5'TCC GTA GGT GAA CCT GCG G-3') and ITS4 (5'-TCC TCC GCT TAT TGA TAT GC-3’) (Amersham Pharmacia Biotech, UK) were used for PCR amplification of ITS 1 and ITS 2 regions, portions of the small (18S) and large (28S) nuclear ribosomal DNA genes, and the 5.8S rDNA. The resulting PCR products were digested using the following endonucleases: Taq

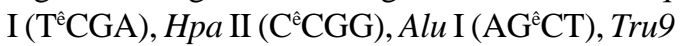
I (TêTAA), Hinf I (GềANTC) (all from Promega Corporation, Madison, USA), Bfa I (CêTAG) and Pst I (CTGCA ${ }^{\mathrm{e} G}$ ) (both from New England BioLabs Inc., USA). The reactions were carried out overnight in hot blocks set at the appropriate temperatures as per the enzyme manufacturers' recommendations.

The digested products were then separated by electrophoresis at $4 \mathrm{~V} / \mathrm{cm}$ for 4 hours on 3.5\% (w/v) MetaphorÒ agarose (FMC Bio Products, Rockland, USA) gels in 0.5X TBE buffer. DNA fragment banding patterns were visualised under UV light after staining for 30 minutes in ethidium bromide solution $(0.5 \mathrm{mg}$ $\left.\mathrm{l}^{-1}\right)$. Sizes of the restriction fragments from ITSRFLP analyses were estimated against a 100base pair (bp) ladder; additionally, GelCompar II software (Applied Maths BVBA, Kortrijk, Belgium) was used for improved size estimation.

Analysis with Cercospora-specific primers. DNA samples from representative isolates of various Cercospora species groups were PCRamplified using C. zeae-maydis-specific primers that target the ITS regions of rDNA (L.D. Dunkle, unpublished data). The primer pair specific to $C$. zeae-maydis group I was CZM1F (5'-GCG ACC CTG CCG TTC-3') and CZM1R (5'-AGC TCA GCC GGA GAC TTT A3'), whilst that specific to C. zeae-maydis group II was CZM2F (5'-GCG ACC CTG CCG TTT3') and CZM2R (5'-CTCAGC CGG AGACTTCG3’), all synthesised by Sigma-Genosys, UK. The PCR products were electrophoresed at $4 \mathrm{~V} / \mathrm{cm}$ for 
2.5 hours through $2 \%$ SeakemÒ LE agarose gels and visualised under UV light after staining for about 30 minutes in ethidium bromide solution $\left(0.5 \mathrm{mg} \mathrm{l}^{-1}\right)$. Sizes of the amplification products were determined as for the ITS-RFLP analyses above

Nucleotide sequence analysis. Analysis of nucleotide sequences of the ITS regions was carried out on a selection of 16 Cercospora isolates obtained from GLS lesions on maize and other hosts in Kenya and other sources. The ITS regions (mainly covering ITS1, ITS2, and the 5.8S subunit) were amplified with primers NS7 (5'-GAG GAATAA CAG GTC TGT GA-3') and PN10 (5'-TTG CCG CTT CAC TCG CCG TT3') (Sigma-Genosys, UK). The PCR products were purified with a DNA purification kit (WizardÒ Plus Minipreps DNA Purification System, Promega Corporation, Madison, USA) according to the manufacturer's instructions in readiness for sequencing. Sequencing reactions were carried out by employing IRDye-labelled primers ITS6-700 (5'-GAA GGT GAA GTC GTA ACAAGG-3') and ITS4-800 (5'-TCC TCC GCT TAT TGA TAT GC-3') (MWG-Biotech, Germany) using the SequiTherm EXCELÔ II DNA Sequencing Kit-LC (EpiCentre Technologies, UK). Electrophoresis was then carried out using the LI-COR Automated DNA Sequencer 4200IR ${ }^{2}$ (LI-COR Inc., Lincoln, USA) set at $1500 \mathrm{~V}, 35 \mathrm{~mA}, 40$ watts, $50{ }^{\circ} \mathrm{C}$, 3 scan speed and 25 frames. The whole procedure was repeated at least once for each isolate to obtain replicate sequences.

The resulting sequences were determined by auto-sequencing each isolate in both directions using BaseImage $\mathrm{IR}^{2}$ software. Subsequently, the replicate base sequences and their corresponding signal traces were examined to correct for any miscalled or ambiguous bases using Chromas software (Griffith University, Queensland, Australia). Sequences were aligned to generate consensus sequences using MacVectorÔ 7.0 software (Oxford Molecular Ltd., UK) and trimmed to obtain a similar length of sequences for all the isolates under comparison. The resulting sequences were compared with sequences published in the Gene Bank (http://www.ncbi.nlm.nih.gov/blast/
Blast.cgi) using a BLAST search option (Altschul et al., 1997). Phylogenetic analysis was carried out on the trimmed sequences using distance matrix methods provided in the MacVectorÔ 7.0 software.

\section{RESULTS}

Identity and distribution of isolates. A total of 146 fungal isolates were selected from the maize leaf samples collected during the extensive GLS biological surveys, covering a wide range of agro-ecological zones in Kenya. A total of 141 (96.6\%) of these isolates were identified as Cercospora zeae-maydis, and the rest as $C$. sorghi var. maydis. Of the five $C$. sorghi var. maydis isolates, two were recovered along with $C$. zeae-maydis on the same leaf samples. Cercospora zeae-maydis was identified from maize leaf materials collected from all parts of the country, whilst $C$. sorghi var. maydis was obtained from samples originating from western Kenya only. The 2008 samplings yielded only C. zeae-maydis as identified through cultural and morphological characteristics of isolates obtained from 67 maize leaf samples.

Leaf samples of hosts other than maize yielded fungi conforming to the morphology of C. sorghi. This fungus was isolated from a total of 14 samples, of which 12 were sorghum leaves and one each of wild sorghum and wild oat. Of the 12 isolates from sorghum, six were from western Kenya, four from the central region and two from the coastal region; the wild sorghum and wild oat samples were from the western and central regions, respectively. Samples of Columbus grass, Sudan grass, Guatemala grass, pearl millet/bulrush millet, napier grass, and sugarcane, as well as some sorghum leaves, yielded fungi that were morphologically dissimilar to Cercospora species and were, therefore, discarded.

Cultural and morphological characteristics of isolates. Isolates that were identified as $C$. zeae-maydis grew very slowly in comparison to the other species, reaching only $1-2 \mathrm{~cm}$ in diameter after more than three weeks at $25^{\circ} \mathrm{C}$ on V8 juice agar. The colonies were compact (hard), 
dome-like, well raised from the medium surface and dark grey to black in colour. Some sectoring was exhibited in culture, whereby whitish-grey mycelial patches developed from the typical greyblack colonies. The $C$. zeae-maydis isolates from Kenyan maize samples were culturally similar to the C. zeae-maydis group II isolate from USA (OYPA16). On the other hand, the C. zeae-maydis group I isolate (SCOH1-5) from USA grew much faster (about $3.5 \mathrm{~cm}$ colony diameter in 3 weeks) and appeared cottony and grey in colour, with a greyish white cast on colony surface.

All the C. zeae-maydis isolates had similar morphological features and no distinction could be made among them. Their conidia were 3-10 septate, straight or slightly curved, hyaline, subcylindrical (mainly in culture) to obclavate (on host) in shape, with gradual tapering to a subobtuse tip and a truncate base. The widest part of the conidia was around the one-third position along the spore length from the base. Septation and conidial scars were more conspicuous on conidia from host tissues than on conidia produced in artificial culture medium.

Isolates identified as either $C$. sorghi or $C$. sorghi var. maydis produced fast-growing colonies, reaching 5-6 cm in diameter after three weeks on V8 juice agar at $25^{\circ} \mathrm{C}$. Colonies of $C$. sorghi var. maydis were prostrate, greyish white or grey in colour, with whitish or pale grey centres and faint concentric ring formations over their woolly surfaces. On the other hand, C. sorghi isolates displayed a wide variety of colours; some were whitish grey, greenish grey or just grey, and colonies were largely low or only slightly raised with light brown to brown diffuse mycelia at the edges. Sectoring in colonies of $C$. sorghi var. maydis and C. sorghi was more pronounced than was the case with $C$. zeae-maydis.

Conidia of C. sorghi var. maydis were 5-12 septate, straight or slightly curved, largely obclavate (culture) in shape and sharply tapering to a sub-acute tip; the conidia had inconspicuous septation. In general, the conidia appeared narrower and more obclavate than those of $C$. zeae-maydis, although a range of sizes was evident in both species. Conidia of $C$. sorghi from sorghum, wild sorghum and wild oat were largely similar to those of $C$. sorghi var. maydis apart from a more conspicuous tapering to a sharper tip.

\section{MOLECULAR IDENTIFICATION OF FUNGI FROM MAIZE AND OTHER PLANTS}

ITS-RFLP analyses. The $C$. zeae-maydis, $C$. sorghi var. maydis, and C. sorghi isolates from Kenya yielded DNA products of about 550 base pairs (bp) in length after amplification of the ITS regions using primer pair ITS1/ITS4 (Table 1). PCR products of a similar size were obtained after amplification of the ITS regions of the representative isolates of $C$. zeae-maydis sibling species I and II from USA, and the type isolates obtained from CABI's Genetic Resource Collection (GRC), which included $C$. beticola (from Beta sp.) and C. longipes (from sugarcane).

Following endonuclease restriction of the ITS-PCR products, varying numbers and sizes of DNA fragments were produced and were dependent on the fungal species and the enzyme used in the reactions. Of the enzymes tested, Taq I, Hpa II, Alu I, Hinf I and Tru9 I produced restriction profiles from the ITS-PCR products, whereas the products of all the Cercospora species remained visibly intact with enzymes $P$ st I and Bfa I. The features of the profile types obtained are described in Table 1 . Figure 1 is an example of the ITS region amplification products and their corresponding Taq I restriction profiles.

\section{Analyses using Cercospora-specific primers.} Primer pair CZM1F/CZM1R amplified rDNA of both C. zeae-maydis group I and $C$. longipes, but produced fragments measuring 310 and 380 bp for the two species, respectively (Table 2). This primer pair did not amplify DNA samples from isolates belonging to the other species groups. On the other hand, primer pair CZM2F/ CZM2R amplified rDNA from all the Cercospora species, albeit with differences in the sizes of the resulting fragments (Table 2). The Kenyan isolates of $C$. zeae-maydis produced a DNA fragment measuring about $310 \mathrm{bp}$, which was similar to the fragments obtained on the $C$. zeae-maydis type-isolate from the GRC 


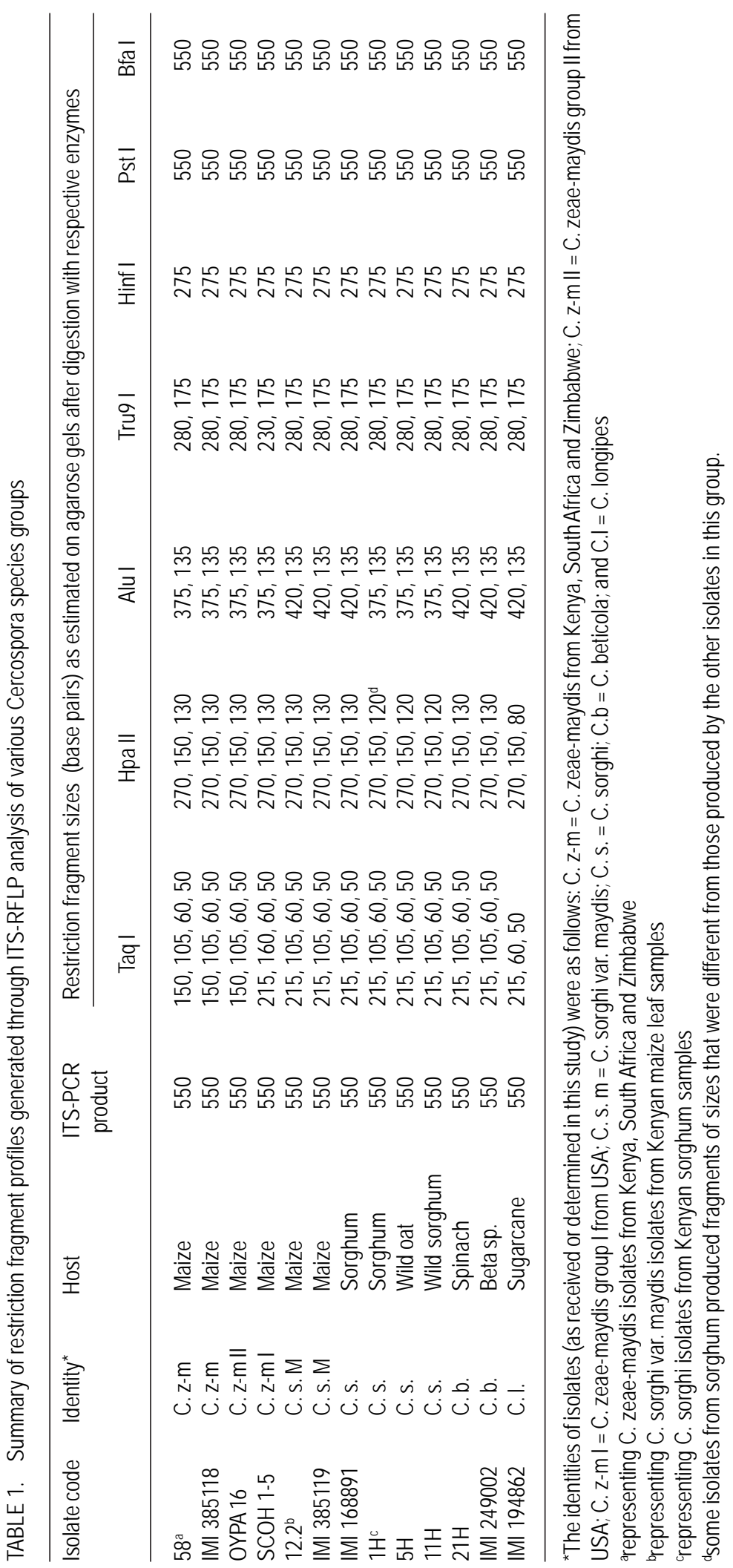




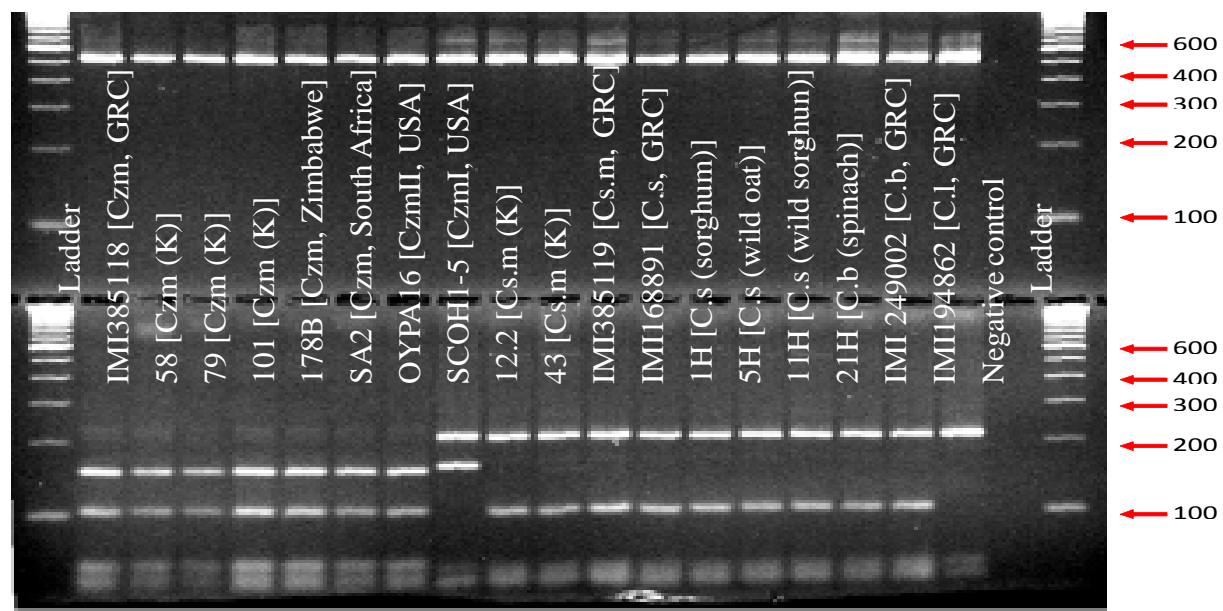

Figure 1. ITS-PCR products (top lanes) and corresponding RFLP patterns (bottom lanes) obtained after restriction digestion of Cercospora isolates with Taq I. Species identities are as shown in square brackets against each isolate: $\mathrm{Czm}=\mathrm{C}$. zeae-maydis from Kenya $(\mathrm{K})$, Zimbabwe or South Africa; CzmII = C. zeae-maydis group II from USA; CzmI = C. zeae-maydis group I from USA; $C$. $. m=C$. sorghi var. maydis from maize; $C . S=C$. sorghi from sorghum or other hosts; $C . b=C$. beticola; and $C . I=C$. longipes. Prefixes IMI indicate isolates from CABI's Genetic Resource Collection. Ladder = 100bp size marker.

(IMI385118) and the C. zeae-maydis group II isolate from USA.

The C. zeae-maydis group I isolate produced a bigger fragment measuring 760 nucleotides. Isolates of $C$. sorghi var. maydis from Kenyan maize, $C$. beticola and the $C$. sorghi type-isolate from sorghum (IMI 168891) yielded fragments of $1,020 \mathrm{bp}$ in length. The $C$. sorghi isolates from Kenyan sorghum, wild oat and wild sorghum produced fragments with 1,070 nucleotides. However, there were a few exceptions amongst the $C$. sorghi isolates: for instance isolates coded $7 \mathrm{H}$ and $14 \mathrm{H}$ produced fragments measuring 515bp and $320 \mathrm{bp}$, respectively whilst isolate $8 \mathrm{H}$ yielded two fragments, one with 1580 nucleotides and the other with 1,070 nucleotides (data not shown). C. longipes DNA was also weakly amplified to produce an 800-bp fragment (data not shown).

Nucleotide sequence analyses. Multiple alignments of the consensus strands obtained from replicate and bi-directional sequences were trimmed to a length of 505 nucleotides for each isolate. BLAST searches using the trimmed sequences led to the identification of the isolates as detailed in Table 3. Nucleotide differences, exhibited as presence (insertions), absence (deletions) and inter-changes (transitions/ transversions), among the isolates were at 28 positions along the aligned sequences. Numerical analyses of the sequence data were carried out on the basis of nucleotide substitutions, where transition and transversion events were considered to occur at different rates (Kimura, 1980), and also on the basis of the absolute number of nucleotide differences. These two approaches grouped or separated the isolates to produce similar species-based clades (Fig. 2).

Cercospora zeae-maydis isolates 11 and 58 from Kenya's maize leaf samples, the $C$. zeaemaydis type-isolate (IMI 385118) and the $C$. zeae-maydis group II isolate (OYPA16) had identical sequences and, therefore, formed a homogeneous clade. This clade diverged from the rest of the Cercospora isolates by a genetic distance of about $0.9 \%$, which was equivalent to an average difference of 4.208 nucleotides (Fig. 2).

Isolates identified as $C$. sorghi var. maydis (9.1, 12.2, and 43) were grouped together with the C. sorghi var. maydis type-isolate (IMI 385119) and the C. sorghi isolate from sorghum (IMI 168891). These isolates constituted a heterogeneous clade with sequence divergence ranging from 0.1 to $0.4 \%$, equivalent to mean nucleotide differences of 0.5 to 1.75 (Fig. 2). 
TABLE 2. Fragment sizes of PCR products generated by amplification of rDNA of various Cercospora species groups using C. zeae-maydis-specific primers

\begin{tabular}{|c|c|c|c|c|}
\hline \multirow[t]{2}{*}{$\begin{array}{l}\text { Representative } \\
\text { isolate code }\end{array}$} & \multirow[t]{2}{*}{ Identity* } & \multirow[t]{2}{*}{ Host } & \multicolumn{2}{|c|}{$\begin{array}{c}\text { Fragment sizes (basepairs) as estimated on agarose gels after } \\
\text { amplification with respective primer pairs }\end{array}$} \\
\hline & & & CZM1F/CZM1R & CZM2F/CZM2R \\
\hline $58^{a}$ & C. $z-m$ & Maize & - & 310 \\
\hline IMI 385118 & C. $z-m$ & Maize & - & 310 \\
\hline OYPA16 & C. $z-m \|$ & Maize & - & 310 \\
\hline $\mathrm{SCOH} 1-5$ & C. $z-m I$ & Maize & 310 & 760 \\
\hline $12.2^{b}$ & C.s.m & Maize & - & 1,020 \\
\hline IMI 385119 & C.s.m & Maize & - & 1,020 \\
\hline IMI 168891 & C.s. & Sorghum & - & 1,020 \\
\hline $1 \mathrm{H}^{\mathrm{c}}$ & C.s. & Sorghum & - & $1,070^{d}$ \\
\hline $5 \mathrm{H}$ & C.s. & Wild oat & - & 1,070 \\
\hline $11 \mathrm{H}$ & C.s. & Wild sorghum & - & 1,070 \\
\hline $21 \mathrm{H}$ & C. $b$. & Spinach & - & 1,020 \\
\hline IMI 249002 & C. $b$. & Beta sp. & - & 1,020 \\
\hline IMI 194862 & C.I. & Sugarcane & 380 & 800 \\
\hline
\end{tabular}

*The identities of isolates (as received or determined in this study) were as follows: $C . z-m=C$. zeae-maydis from Kenya, South Africa and Zimbabwe; C. z-m II = C. zeae-maydis group II from USA; C. Z-m I = C. zeae-maydis group I from USA; C. s. $m=C$. sorghi var. maydis; $C$. ..$=C$. sorghi; $C . b=C$. beticola; and C.I = C. longipes

arepresenting $C$. zeae-maydis isolates from Kenya, South Africa and Zimbabwe brepresenting $C$. sorghi var. maydis isolates from Kenyan maize leaf samples crepresenting $C$. sorghi isolates from Kenyan sorghum samples ${ }^{\mathrm{d}}$ some isolates from sorghum produced fragments of sizes that were different from those produced by the other isolates in this group

The C. sorghi isolates recovered from sorghum and wild sorghum formed another separate clade; isolates within this clade differed from each other by a sequence divergence of about $0.1 \%$ ( 0.5 nucleotide difference) and, therefore, this clade was more homogenous than that of C. sorghi var. maydis. Isolate SCOH15, representing $C$. zeae-maydis group I population, was closely related to the $C$. sorghi clade, but with a sequence divergence of $0.5 \%$ (2.25 nucleotide differences) (Fig. 2). C. sorghi from wild oat (isolate $5 \mathrm{H}$ ) also loosely clustered with the other $C$. sorghi isolates but at a much higher distance (0.6\% divergence) than the $C$. zeae-maydis group I isolate (Fig. 2).

\section{DISCUSSION}

Isolates obtained from maize production ecosystems were identified as C. zeae-maydis, $C$. sorghi var. maydis or $C$. sorghi by matching their conidial morphology and cultural growth characteristics to those observed on the available type-isolates, and with reference to their hosts. The characteristics observed largely conformed to published descriptions given by various authors (Chupp, 1953; Mulder and Holliday, 1974; David, 2001). In general, isolates belonging to any one species seemed to cover a wide range of characteristics in terms of both the conidial shape and sizes, and the cultural growth habits. It was often evident that these characteristics overlapped the species delimitation. As a result, it was often necessary to consider a combination of both the conidial morphology and cultural characteristics to assign each isolate a species identity. This observation corroborates the experience of Meisel et al. (2009) who reported very strong morphological similarities of fungi associated with the grey leaf spot disease of maize.

ITS-RFLPs revealed varying levels of discrimination and clustering of the isolates by the enzymes that were employed. Among the 
TABLE 3. Identification of Cercospora isolates from maize and other hosts by BLAST searches ${ }^{1}$ of nucleotide sequences

\begin{tabular}{|c|c|c|c|c|c|}
\hline Isolate code ${ }^{2}$ & Host & Country & Identity & $\begin{array}{c}\text { Gene Bank } \\
\text { accession } \\
\text { No. of identifying } \\
\text { strain }\end{array}$ & $\begin{array}{l}\text { Nucleotide } \\
\text { similarities }\end{array}$ \\
\hline 11 & Maize & Kenya & C. zeae-maydis group II & AF291710 & $501 / 503$ \\
\hline 58 & Maize & Kenya & C. zeae-maydis group II & AF291710 & $501 / 503$ \\
\hline IMI 385118 & Maize & Kenya & C. zeae-maydis group II & AF291710 & $501 / 503$ \\
\hline OYPA16 & Maize & USA & C. zeae-maydis group II & AF291710 & $501 / 503$ \\
\hline $\mathrm{SCOH} 1-5$ & Maize & USA & C. zeae-maydis group I & AF291709 & $499 / 503$ \\
\hline 9.1 & Maize & Kenya & C. sorghi var. maydis & AF297232 & $500 / 502$ \\
\hline 12.2 & Maize & Kenya & C. sorghi var. maydis & AF297232 & $501 / 502$ \\
\hline 43 & Maize & Kenya & C. sorghi var. maydis & AF297232 & $500 / 502$ \\
\hline IMI 385119 & Maize & Kenya & C. sorghi var. maydis & AF297232 & $501 / 502$ \\
\hline IMI 168891 & Sorghum & PNG* & C. sorghi var. maydis & AF297232 & $500 / 502$ \\
\hline $2 \mathrm{H}$ & Sorghum & Kenya & C. sorghi & AF291707 & $500 / 504$ \\
\hline $3 \mathrm{H}$ & Sorghum & Kenya & C. sorghi & AF291707 & $499 / 504$ \\
\hline $5 \mathrm{H}$ & Wild oat & Kenya & C. sorghi & AF291707 & $484 / 487$ \\
\hline $7 \mathrm{H}$ & Sorghum & Kenya & C. sorghi & AF291707 & $501 / 504$ \\
\hline $11 \mathrm{H}$ & Wild sorghum & Kenya & C. sorghi & AF291707 & $501 / 504$ \\
\hline IMI 249002 & Beta sp. & Germany & C. beticola & AF297222 & $505 / 505$ \\
\hline
\end{tabular}

${ }^{1}$ Searches were done in the Gene Bank of the National Center for Biotechnology Information (NCBI), http:// www.ncbi.nlm.nih.gov/blast/Blast.cgi

2 Prefix IMI shows isolates obtained from CABI's Genetic Resource Collection; OYPA16 and SCOH1-5 were provided by L.D. Dunkle, Purdue University, USA; all the other isolates were collected from hosts in Kenya during the current study *PNG = Papua New Guinea

enzymes tested, a combination of the separate profiles generated by Taq I and Hpa II proved very useful in grouping the fungal isolates into the different species. With Taq I, all the C. zeaemaydis isolates from Africa (Kenya, South Africa and Zimbabwe) produced DNA profiles that were similar to those exhibited by the typeisolate IMI 385118 from CABI's Genetic Resource Collection (GRC) and the C. zeaemaydis group II isolate (OYPA16) from USA. The profiles had two large fragments measuring 150 and 105bp, in addition to other smaller ones. These results are consistent with those reported by Wang et al. (1998), who obtained similar fragments measuring 153 and 102bp on C. zeaemaydis group II isolates upon restriction digestion of ITS5/ITS4-PCR products with the same enzyme. These isolates were clearly distinct from the C. zeae-maydis group I isolate as well as the $C$. sorghi var. maydis and $C$. sorghi isolates. The latter two species could not be differentiated by Taq I. By employing Hpa II, these two species produced different profiles, with a few exceptions where some of the $C$. sorghi isolates shared a similar profile with $C$. sorghi var. maydis as well as $C$. zeae-maydis group I, $C$. zeae-maydis group II, and C. beticola.

The grouping of the isolates as C. zeaemaydis group I, C. zeae-maydis group II, C. sorghi var. maydis or $C$. sorghi was further supported by the analyses carried out using $C$. zeae-maydis-specific primers, whereby fragments of different sizes were obtained for different species. In this study, the specificity of the C. zeae-maydis-specific primers on $C$. zeae-maydis group I and C. zeae-maydis group II was as determined by L.D. Dunkle (personal communication). All the C. zeae-maydis isolates yielded amplification products that matched the size of PCR products derived from the C. zeaemaydis group II isolate (OYPA16) when primer pair CZM2R/CZM2F was used; none of these isolates was amplified by primer pair CZM1R/ CZM1F, which amplified the C. zeae-maydis group I isolate. 

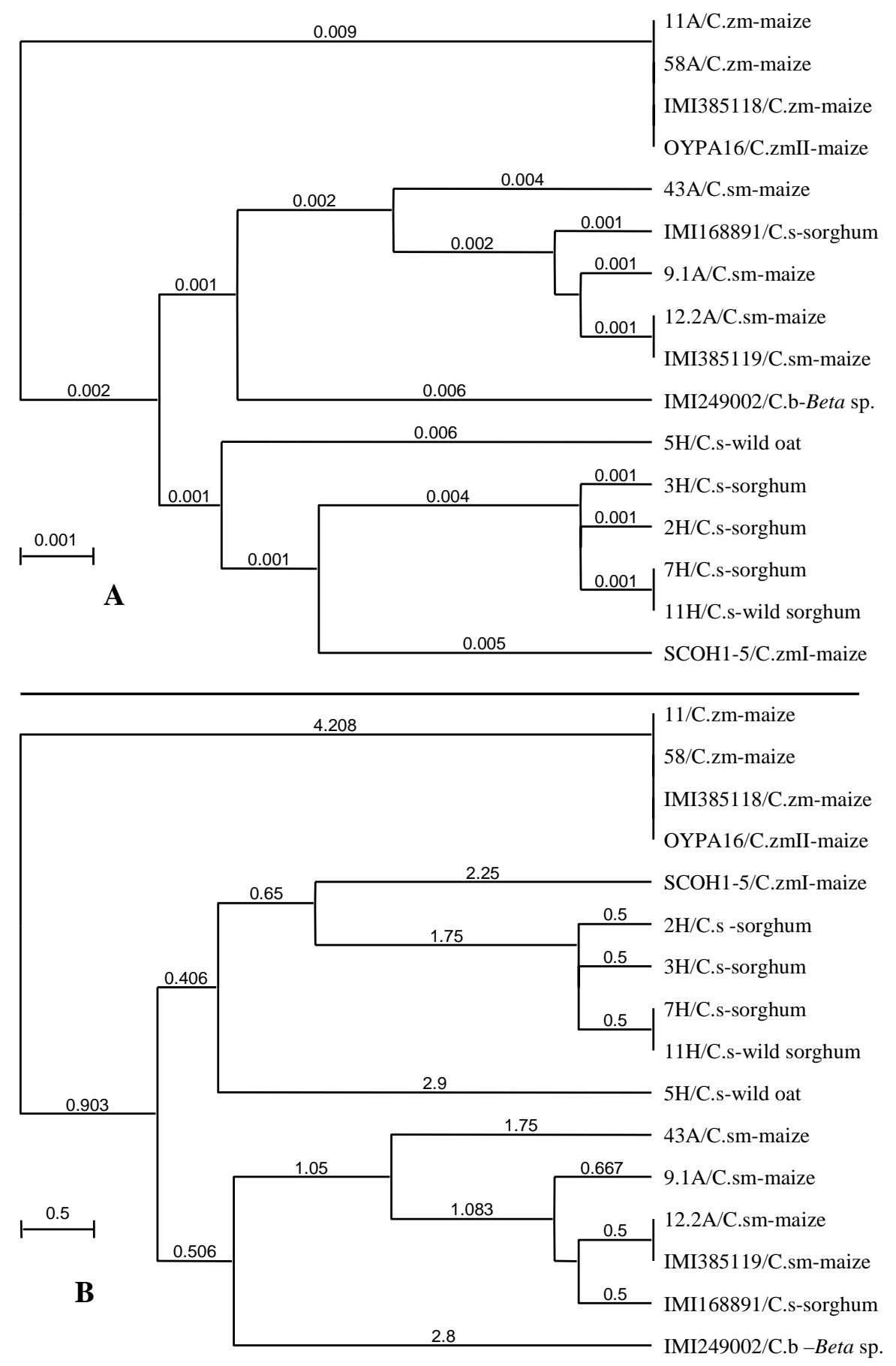

Figure 2. Dendrograms based on analysis of nucleotide substitution (A) and absolute number of nucleotide differences (B) in ITS regions of Cercospora species isolated from maize and other hosts. The trees were reconstructed using the UPGMA algorithm (Best Tree option) on multiple alignment data of the isolate sequences. Scale bar in A indicates a $0.1 \%$ sequence divergence (Kimura 2-parameter with transition : transversion ratio of 3.04) whilst the scale bar in B reflects a 0.5 nucleotide difference. Isolate codes are followed by species and host identities. C.zm = C. zeae-maydis (I for group I \& II for group II); C.sm $=$ C. sorghi var. maydis; C.s $=$ C. sorghi; $\mathrm{C} . \mathrm{b}=\mathrm{C}$. beticola. 
Sequence analysis of the ITS regions was consistent with the above grouping of isolates into different species. Additionally, the sequence data provided some insight into the phylogenetic relationships between $C$. zeaemaydis group II and the other Cercospora species; the C. zeae-maydis group II population was clearly distinct from all the other species groups analysed during this study. Isolates in this population were also found to be highly homogenous, indicating that the isolates belonged to one clonal lineage. This strongly corroborates the observation that the fungus, and the disease, is a recent entry into the country.

On the basis of the predominance of $C$. zeae-maydis group II in Kenya, and previous investigations that have confirmed its presence in South Africa, Zimbabwe, Zambia and Uganda (Dunkle and Levy, 2000; Crous et al., 2006; Meisel et al., 2009), it can be inferred that GLS in Kenya, and Africa in general, is principally caused by this fungus. Even with the extensive sampling carried out during the surveys in this study, C. zeae-maydis group I, which is reported to occur in USA (Wang et al., 1998), was not detected among the isolates from maize production ecosystems. Therefore, there is great confidence that $C$. zeae-maydis group I is not endemic to Kenya at the moment. A similar deduction has also been made for the case of southern Africa (Meisel et al., 2009). However, the existence of this fungus elsewhere shows that it may be only a matter of time before it spreads into Africa and other regions.

Cercospora sorghi var. maydis was recovered from a few of the maize leaf samples (less than $4 \%$ of the cases) and only in the western Kenya region. This fungus has previously been associated with GLS lesions on maize (Chupp, 1953; Pollack, 1987; Shurtleff, 1992; White, 1999) and some isolates from Kenya have been used in previous studies (Carson et al., 2002). Although, it appears prudent to devote most of the efforts towards managing C. zeaemaydis group II, the co-existence of the two fungi in the same maize production environments, and indeed on the same leaf samples, suggests that C. sorghi var. maydis also deserves some consideration. For example, it would be important to evaluate the stability of resistance/tolerance of maize genotypes to isolates representing both C. zeae-maydis group II and C. sorghi var. maydis populations.

Although maize was occasionally planted in close proximity to where $C$. sorghi hosts such as sorghum, wild oat and wild sorghum were growing, neither C. zeae-maydis nor C. sorghi var. maydis was isolated from such hosts. Conversely, none of the isolates from maize conformed to the $C$. sorghi identity. This observation shows that GLS pathogens of maize are not harboured by sorghum and other hosts, and therefore, such hosts are not a direct source of inoculum for maize fields.

\section{REFERENCES}

Altschul, S.F., Madden, T.L., Schaffer, A.A., Zhang, J., Zhang, Z., Miller, W. and Lipman, D.J. 1997. Gapped BLAST and PSI-BLAST: a new generation of protein database search programmes. Nucleic Acids Research 25: 3389-3402.

Anonymous 1989. Ministry of Agriculture Report. Government Printer, Nairobi, Kenya.

Carson, M.L., Goodman, M.M. and Williamson, S.M. 2002. Variation in aggressiveness among isolates of Cercospora from maize as a potential cause of genotype-environment interaction in gray leaf spot trials. Plant Disease 86:1089-1093.

Chupp, C. 1953. A monograph of the fungus genus Cercospora. Ronald Press Co., New York, USA.

Crous, P.W., Groenewald, J.Z., Groenewald, M., Caldwell, P., Braun, U. and Harrington, T.C. 2006. Species of Cercospora associated with grey leaf spot of maize. Studies in Mycology 55:189-197.

David, J.C. 2001. Cercospora zeae maydis. IMI descriptions of Fungi and Bacteria. No. 1437. CAB International, UK.

Dunkle, L.D. and Levy, M. 2000. Genetic relatedness of African and United States populations of Cercospora zeae-maydis. Phytopathology 90:486-490.

Export Processing Zones Authority 2005. Grain production in Kenya. Export Processing Zones Authority. 20pp. 
Kimura, M. 1980. A simple method of estimating evolutionary rate of base substitutions through comparative studies of nucleotide sequences. Journal of Molecular Evolution 16:111-120.

Latterell, F. M. and Rossi, A. E. 1983. Gray leaf spot of corn: a disease on the move. Plant Disease 67:842-847.

Meisel, B., Korsman, J., Kloppers, F.J. and Berger, D.K. 2009. Cercospora zeina is the causal agent of grey leaf spot disease of maize in southern Africa. European Journal of Plant Pathology 124(4):577-583.

Mulder, J.L. and Holliday, P. 1974. Cercospora sorghi. CMI Descriptions of Pathogenic Fungi and Bacteria. No. 419. Commonwealth Agricultural Bureaux. England.

Muriithi, L.M. and Gathama, S.K. 1998. Gray leaf spot of maize: a new disease on increase. Crop Protection Newsletter.

Pollack, F.G. 1987. An annotated compilation of Cercospora names. Mycologia Memoir 12. 212pp.

Raeder, U. and Broda, P. 1985. Rapid preparation of DNA from filamentous fungi. Letters in Applied Microbiology 1:17-20.
Saghai-Maroof, M.A., van Scoyoc, S.W., Yu, Y.G. and Stromberg, E.L. 1993. Gray leaf spot disease of maize: Rating, methodology and inbred line evaluation. Plant Disease 77: 583587.

Shurtleff, M.C. 1992. Compendium of Corn Diseases (second edition). The American Phytopathological Society, USA.

Wang, J., Levy, M. and Dunkle, L.D. 1998. Sibling species of Cercospora associated with gray leaf spot of maize. Phytopathology 88:12691275.

Ward, J.M.J., Birch, E.B. and Nowell, D.C. 1993. Grey leaf spot on maize. Co-ordinated extension: Maize in Natal. Cedara Agricultural Development Institute, Pietermaritzburg, Republic of South Africa.

Ward, J.M.J., Laing, M.D. and Rijkenberg, F.H.J. 1997. Frequency and timing of fungicide applications for the control of gray leaf spot in maize. Plant Disease 81:41-48.

White, D.G. 1999. Compendium of Corn Diseases (Third Edition). The American Phytopathological Society, Minnesota, USA. 